UDC 811: 801.3

DOI https://doi.org/10.32782/tps2663-4880/2021.15.21

\title{
GLOBALIZATION AS A FACTOR IN THE DEVELOPMENT OF LANGUAGE PROCESSES
}

\section{ГЛОБАЛІЗАЦІЯ ЯК ФАКТОР РОЗВИТКУ МОВНИХ ПРОЦЕСІВ}

\author{
Yunusova Narmina \\ orcid.org/0000-0003-1739-6550 \\ Dissertation at the Department of General Linguistics \\ Azerbaijan State University of Languages
}

Social development has always been closely linked with scientific and technological progress. In the second half of the 20th century, an information leap took place, which marked the acceleration in the global scale of information exchange, as well as the global coverage of the Earth by the Internet. Information exchange also plays an essential role in coordinating all spheres of social activity. In this regard, the global approach has confirmed its need for a joint search and solution of common problems for mankind. Four stages in the history of the development of globalization are associated with handicraft, manufacturing, mechanization and automation. A closer look at each of these stages, you can see, above all, changes in the production process. The article reviews the impact of the phenomenon of globalization on the regular processes of social development. If we approach globalization from the point of view of Azerbaijan's political interests, we can note that Azerbaijan, as one of the participants in this process, began to implement educational reforms with the goal of forming specialists who can work in new realities. Participation in a number of international projects and joining the Bologna Process shows that significant steps have been taken in this direction. At the same time, it is difficult to say that the education system in Azerbaijan began to receive positive incentives in the context of globalization. The West supplies the ready-to-use form of the education programs. Such an approach will help educate people who are hostile to their cultural, moral and spiritual values. In general, it can be concluded that the education, as a potential development factor, needs fundamental changes in the conditions of globalization. Based on this, it is necessary to make the necessary changes in the methodology and didactics of education, based on the latest information technology.

Key words: globalization, social norms, information technologies, languages in the conditions of globalization, localization, education technologies, bilingualism.

Соціальний розвиток завжди був тісно пов'язаний з науково-технічним прогресом. У другій половині XX століття відбувся інформаційний стрибок, який ознаменувався прискоренням глобальних масштабів обміну інформацією, а також глобальним охопленням Землі Інтернетом. Обмін інформацією також відіграє важливу роль у координації всіх сфер соціальної діяльності. У зв'язку з цим глобальний підхід підтвердив необхідність спільного пошуку та вирішення загальних проблем людства. Чотири етапи в історії розвитку глобалізації пов'язані з ремеслом, виробництвом, механізацією та автоматизацією. Під час детальнішого розгляду кожного з цих етапів можна побачити перш за все зміни у виробничому процесі. У статті розглянуто вплив явища глобалізації на регулярні процеси суспільного розвитку. Якщо підходити до глобалізації з точки зору політичних інтересів Азербайджану, можна зазначити, що Азербайджан як один із учасників цього процесу почав впроваджувати освітні реформи задля формування спеціалістів, здатних працювати в нових реаліях. Участь у низці міжнародних проєктів та приєднання до Болонського процесу свідчать про те, що в цьому напрямі зроблено значні кроки. Водночас важко сказати, що система освіти в Азербайджані почала отримувати позитивні стимули в умовах глобалізації. Захід забезпечує готову до використання форму навчальних програм. Такий підхід допоможе виховати людей, які вороже ставляться до своїх культурних, моральних та духовних цінностей. Загалом можна зробити висновок, що освіта як потенційний фактор розвитку потребує принципових змін в умовах глобалізації. 3 огляду на це необхідно внести необхідні зміни в методологію та дидактику освіти з урахуванням новітніх інформаційних технологій.

Ключові слова: глобалізація, соціальні норми, інформаційні технології, мови в умовах глобалізації, локалізація, освітні технології, двомовність.

Problem statement. In terms of the fate of the national existence of nations in the context of globalization, the principal aspects of the prospects for the development of language and the factors influencing this development are defined as follows. The process of globalization is permeating all spheres of society and human activity. This sustainable process is different in countries with different levels of development, with both positive and negative impacts. Due to its large-scale, comprehensive and contradictory nature, globalization threatens the loss of language and culture, customs and tradi- tions in the peoples of the world. Modern information and communication means, especially the Internet, widely interfere in the interaction of the subjects of globalization. Globalization is also the rapprochement of nations and their resemblance to each other's way of life. In this case, the development of national cultures and the protection of their specificity should be given special attention. Social development has always been closely linked with scientific and technological progress. In the second half of the 20th century, an information leap took place, which marked the acceleration in the global scale of information 
exchange, as well as the global coverage of the Earth by the Internet. Information exchange also plays an essential role in coordinating all spheres of social activity. In this regard, the global approach has confirmed its need for a joint search and solution of common problems for mankind.

Analysis of recent research and publications. The impact of globalization on various factors has been the subject of research for many years. However, the relationship of globalization to language processes has been less studied. This connection has been analyzed in the English literature, especially in the works of authors such as M. Burawoy, A. Cameron, R. Palan, N. Chomsky, L. Chouliaraki, N. Fairclough, M. Duffield, S. Eizenstat, N. Fairclough, J. Habermas, T. Honderic, B. Jessop, B. Jordan, K. Polanyi. Although the paper "Globalization as a Factor in the Development of Language Processes" is based on the scientific work of the named authors, other works have been used as a reference. These works are "The Clash of Fundamentalisms: Crusades, Cihads and Modernity" by T. Ali [1], "The Trouble with Anthony Giddens: Problems of Status and Structure in Structuration Theory" by J. Graaff [2], "Logic of globalism" by I. Medvedeva [3], "Temptation by globalism" by A. Panarin [4], "Third wave" by E. Toffler [5], "Anxieties of the world: Social consequences of globalization of world processes" [6], "Globalization: process and comprehension" by A. Utkin [7] and others.

Presentation main material. Four stages in the history of the development of globalization are associated with handicraft, manufacturing, mechanization and automation. A closer look at each of these stages, you can see, above all, changes in the production process. These are productivity, quality improvement, and lower production costs. On the whole, according to A. Toffler, in these changes the increase in labor productivity and the desire to reduce the cost price come to the fore. In general, according to A. Toffler, in the period of handicraft and manufacture, the main thing was the use of land and labor. The industrial revolution that took place during the period of mechanization and automation turned capital into the most significant productive force. The third period, which began in the $90 \mathrm{~s}$ of the XX century, turns information into the main force [5, p. 28].

It is believed that globalization contributes to the stable development of states, ensuring the integrity and sustainability of management systems, overcoming bias in economic relations, and increasing the level of people's well-being. Undoubtedly, the supremacy of international principles and norms, the evolutionary nature of changes, mutual trust and devotion to universal human values also provide for the consideration of the characteristic national specialities of each country, as the determining direction of this process.

There are various approaches to globalization. Some scholars have a negative attitude towards globalization, believing that this is the destruction of national culture, denial of the independence of states, the forcible application of sensible production standards in society. Globalization is applied in the same way as a war of civilizations, or a clash of civilizations. Globalists and anti-globalists differ in their attitude to globalization. But what globalization can still give people remains a big mystery. Opponents of globalization are convinced that globalization is a well-thought-out and launched mechanism of domination over the entire world.

Westernization, which is the result of globalization, has changed the norms and stereotypes of behavior, has become a threat to the sovereignty of the nation-state. Currently, globalization is manifested in all spheres of life. It is emphasized that globalization manifests itself more in politics, culture and economics. The political wing of globalization is international political and economic unions, transnational organizations such as Amnesty International, Transparency International, the European Court of Human Rights, the European Human Rights Committee (HRW) and others, as well as international organizations such as the EU, NAFTA and the UN. In other words, economic, political, social, cultural and other powers seem to be in the hands of the relevant authorities. The global hegemony of the United States is felt in the political arena. The United States has an impact on all areas of life. Globalization has become the ideology of the United States.

From the point of view of culture, globalization manifests itself in the localization of social norms, the emergence of liberal democratic values. Globalization continues to influence cultural and social life, lifestyle, culture through the Western way of thinking, the influence of their customs and traditions.

Globalization is very active in the economic sphere. Globalization in the economic sphere is manifested in the unification of national economic systems into a single economic system, the emergence of independence between them, and thereby - the liberalization of all economic relations.

Factors on the political spectrum of globalization include: 1) the place of the United States as the unrivaled position of the world leader; 2) the influence of the United States on the International Monetary Fund and the World Bank; 3) the activities of non-governmental organizations funded by foreign states; 
4) limiting the possibility of implementing independent fiscal and monetary policies and programs by national governments.

Globalization, as a complex event, attracts attention for its versatility and internal contradictions. Some researchers do not accept its objective nature, showing that it is directed by forces from certain centers, and it serves certain, specific interests [4, p. 163].

The sources of the globalization process are very different. There are changes in the social life of society, which determine the trend of globalization [6, p. 10]. The main sources of globalization processes are technical-economic, political and socio-cultural spheres.

There are general trends in globalization. One of the essential factors of its development is the rapid changes in technology, especially in the field of electronics, communications, and transport. Rapid progress in the development of digital technologies has allowed the rapid formation of the global information environment. Advances in technology on an Earthscale have reduced the cost of collecting, processing and transmitting information. New technologies are paving the way for the restructuring of labor relations. Shortening the distance, the instant transmission of information, whether inside or outside the country, affects power relations.

Media is an important factor in globalization. This is due to the launch of both satellite and cable television. Costs associated with digital broadcasting have been significantly reduced. At the same time, the choice of channels is expanding.

A review of the scientific literature on the problems of globalization shows that various aspects of globalization have been studied. The essence of globalization is that production is organically linked with science; new production methods based on new information technologies are formed. Globalization is the materialization of information technology, the removal of administrative barriers between countries; these are financial flows, competition, and information.

Globalization, as a leading process of our time, is shaping a new worldview. Globalization, which plays the role of an objective process for building the future of the world, has become the object of research in various fields of science. There is no doubt that globalization affects the language processes in the world. To determine the role of the media, the study of language and the problem of globalization is necessary, first of all, to show the open nature of the globalization process, the sources of globalization of communication, as well as the essence of global communication, global trends in the media industry.
In the last quarter of the 20th century, important events took place in the world. These processes have also influenced the exchange of information in the world. Among the reasons for the emergence of such processes associated with globalization trends, there are significant changes that occupy a special place. The sudden and rapid expansion of the boundaries of knowledge in this area has sufficiently increased the ability of people to receive a variety of information. Those who join the more active exchange of information become direct participants in the events.

The use of computer telecommunications network allows you to connect to events in real time. Together with computer access to telecommunication networks in time and space, it eliminates national borders and allows individual institutions to join the world community. Globalization, on the one hand, contributes to the convergence of socio-economic and cultural levels of countries, on the other hand, is characterized by the distance and placement of people. One of such contradictions is the partial placement of global communication and materials in the media [7, p. 124].

I. Medvedeva believes that these processes go through the stages of "localization, regionalization and globalization". The global hegemony of the United States is expressed in political, economic and social policy. This is very close to the truth. Because America's influence is visible in all walks of life. In this sense, globalization has become the modern ideology of America [3, p. 196].

To understand the nature of globalization and an adequate response to it, a clear understanding of its results is required. The following main results are noted: dynamic growth of the world economy; increasing unevenness in the development of the world economy, strengthening civil inequality; increased instability in the global economy; changing the role of actors in the global economy; strengthening of regional integration processes; increased global competition and changes in its nature; elimination of the cultural originality (national identity) of individual countries.

According to supporters of radical globalization, the formation of a system of nation states during the period of industrialization is losing its significance in today's new era. Supporters of globalization value market relations over politics; they believe that politicians are gradually reducing their influence on people's lives. Politics and politicians still retain their positions in influencing local and national territories, but they have lost their power to intervene in the global economy. According to Giddens, in many countries, one of the main reasons for the decline 
of citizens' interests in politics and the expectations of politicians is precisely this fact. In other words, "the market is stronger than the state" [2] - this thesis is the main argument in the position of radical globalists.

Skeptics, in a word, antiglobalists, as Giddens aptly stated, question the success of globalization in all directions. In their opinion, globalization is not an attempt to advance, but an attempt to return. The well-known representative of skeptics Gerbier presents globalization as "economic imperialism", for Chomsky it is "the tyranny of totalitarian institutions".

Transformation representatives perceive globalization as a strong economic, social and political factor that has created modern societies and the international political system. They believe that all this will have a serious impact on the functioning of governments and states, but opinions differ that "the end of nation states" will come, "nothing changes in the world". Nevertheless, the transformationists in their positions are close not to skeptics, but to radicals. Globalization contributes to the expansion, contraction, deepening and acceleration of social relations in the context of space and time. For these reasons, globalization can be characterized in the following aspects: 1) globalization is viewed as a phenomenon, without a positive or negative assessment, which is needed for analytical reflection and must be resolved; 2) globalization is a phenomenon that goes beyond the paradigm of the nation-state; 3) globalization is turning into a planning process based on the requirements for the participation of local authorities and institutions of an open society.

There is no doubt that along with the positive features of globalization, which it has brought into human life, there are also negative features. Some researchers defend the idea that globalization is aimed at creating a unified world system. In the context of globalization, there are different opinions among researchers regarding the goals that should be protected. Both high and low goals are associated with the preservation and development of national statehood from the pressure of globalization. Within the political boundaries that span every nation state, there is no other political authority or political structure that can protect the well-being and happiness of its citizens. In the second half of the 21st century, Western intellectuals expecting a big breakthrough from the East are right in this sense. This will show itself both in literature and in technical progress. Japanese and Koreans, as well as representatives of post-Soviet countries, must create a culture that will be needed not only in modern, but also in tomorrow's society. Islamic culture is not hostile to other cultures, human existence is perceived as a value that requires more and more enrichment.

Conclusions. People, humanity must consciously strive for directed globalization. Considering that globalization is a process that takes place and develops outside our will, it is necessary to seriously prepare for it. Azerbaijan should start the process of globalization with learning. Azerbaijan, as one of the members of the globalization process, began with reforms in the field of education in order to form personnel who can adapt to modern realities. Azerbaijan takes part in a number of international educational projects; certain steps have been taken to join the Bologna process. Nevertheless, it is difficult to say that the process of globalization in a positive way benefits the education system. Ready-made educational programs from the West are accepted. This type of education system can form specialists who are alien to the moral, spiritual and cultural values of the people, alien to the people themselves. In general, it can be concluded that education, as a potential factor of development, needs specific reforms in the information society. In general, information technology, and especially interactive multimedia, should be included in the educational process.

\section{REFERENCES:}

1. Tariq A. The Clash of Fundamentalisms: Crusades, Cihads and Modernity. London : Verso, 2003. 342 p.

2. Johann G. The Trouble with Anthony Giddens: Problems of Status and Structure in Structuration Theory. South African Sociological Review. 1993. № 1. P. 35-51.

3. Медведева И., Шишова Т. Логика глобализма. Наш современник. 2001. № 11.

4. Панарин А. Искушение глобализмом. Москва : Эксмо, 2002. 415 с.

5. Тоффрлер Э. Третья волна. Москва : АСТ, 2008. 569 с.

6. Уткин А. Глобализация: процесс и осмысление. Москва : Логос, 2002. 271 с. 